\title{
The Literacies Effectiveness of Short Story Writing Learning Model
}

\author{
Sitti Rachmie Masie \\ Graduate School, Universitas Negeri Malang, Indonesia \\ Wahyudi Siswanto \\ Graduate School, Universitas Negeri Malang, Indonesia \\ Yuni Pratiwi \\ Graduate School, Universitas Negeri Malang, Indonesia \\ Heri Suwignyo \\ Graduate School, Universitas Negeri Malang, Indonesia
}

\begin{abstract}
This research method was a development research employing Borg and Gall (R \& D) model which aims at developing short story writing learning material. The research steps were: (1) conducting a preliminary study or research to find the research findings related to the product, (2) developing the product based on the preliminary study, (3) conducting the field test, and (4) revising the product to improve the weaknesses found during field trials. The results of the study showed that first, the quality of short story writing learning requires creative strategies to achieve learning objectives. Second, the results of text-writing learning model assessment using conversion text encompassing entrepreneurial values obtained a positive score from the expert test, practitioner test, small field test, and extensive field test. Third, the learning model of short story writing with text conversion strategy encompassing entrepreneurial values can significantly improve the ability of students to write short stories compared to conventional models.
\end{abstract}

Index Terms - short stories learning, text conversion strategy, literacies

\section{INTRODUCTION}

The selection of creative learning strategy could generate a captivating and interesting innovation and in addition, it can encourage students to obtain knowledge independently. In particular, writing course requires an extra attention. Within writing course, one of the competencies is short story writing skill. Short story writing aims at encouraging students in making literary works, particularly short story. Through a competence of short story writing students can develop their imagination and able to response to its current life dilemma. Supplementary, short story writing deals with creativity establishment of the students. By composing creative literary works, indirectly, students will be able to motivate themselves, develop critical thinking, possess high imagination, activate a precise life goal, and communicate with their own native language.

The importance of creative writing for college students is to obtain a wide knowledge and insight around their surrounding. The process of creative writing activity could not be separated from the reading activity. During creative writing activity, students are demanded to read various kinds of references such as books, articles, newspapers, magazines, and journals. In addition to above-mentioned resources for creative writing, college students are demanded to be able to capture real-life experience and issues around them through self-sensitivity and curiosity. As an author, curiosity and self-sensitivity are the primary sources in composing good writing. Every single piece works of the author come from author's curiousity or author's response to the reality around them. Hasanah and Siswanto (2013) explain that during the process of composing a short story, a number of aspects within human beings are activated such as attention, observation, response, fantasy, memory, mind, feeling, and any other motive.

In the process of creativity, thinking process aspect is inseparable. Fisher (2002) explains that the goal of thinking is to develop literacy skills, organize human experience, as a valuable means to stimulate discussion activities. The power of the story is in the process of creativity to create the world as an object of intellectual inquiry as well as a challenging intellectual construction.

The important reason to think according to Fisher, Douglas and Gay Ivey (2002) are as follows. First, the ability to think can be used and applied to solve problems, improve reasoning, enable conceptual ability, and encourage analysis ability required within the society in the long-run. The second is the capability of thinking students. Students who possess the ability to think, the level of presentation function increase. Most students do not acquire the skills to obtain ideas from different readings. Only a few number of students possess problem-solving skills and thinking strategies. The decline of students in critical, creative, analysis, synthesis and evaluation thinking leads to weak ability to solve 
problems. This is a fundamental reason for developing thinking skills in learning activities, particularly writing competency. Thirdly, in regard to learning methods, the classroom teaching process is dominated by lecturers with verbal information. This suggests that most teachers do not use methods that can develop students' critical and creative thinking skills.

Therefore, this present study provides a direct learning solution to writing course, particularly short story writing. Direct learning according to Eggen and Don Kauchak, 1996: 367-368) is to apply learning method using four phases, namely introductory phase, material presentation phase, guided training, and self-training phase. The purpose of each phase is to attract attention, encourage engagement in working together, develop skills, and ensure learners accomplishment.

A text conversion strategy is a learning strategy that passes through the process of reading and writing, which involves the creative thinking process. Stages of the reading process, namely: reading the text, understanding, and analyzing the text. Creative stages according to Jauhari (2013: 14) are the stage of idea construction, development, creation, and refinement. The construction of ideas relates to the knowledge and experience that its appearance can be stimulated. The development of ideas could be encouraged by reading, adding experiences, contemplation, discussion, and observation. The creation of ideas is a supportive psychological state, adequate language, and lots of practice. While the refinement of ideas is expressed directly or indirectly, perfected by the author or others through perfection once or more.

The news text is part of the short story writing media. The selection of news as a media for short story writing is due to the characteristics of news as a live depiction and has a function as a real information delivery. In addition, the news provides pictures and sounds, therefore the information and messages are delivered easily and can be digested and understood by the students. Supplementary, it possesses an unlimited distance and time, easier tying and giving associations within the individuality of the student. By employing news as a media for short story writing activity, it decorates students' work to be more colorful and strong impression as if it is happening in a real life.

Anshori, et al. (2005:90) argue that news is a collection of fact or information which is written by journalist and it is reported and published in media. It is commonly published in newspaper, magazine, radio or television. Relevant to the above-mentioned principle, a piece of news is generally composing from particular events occurring in real life. However, not all events happening are defined or met the characteristics of news. The aims of employing news media are to encourage a motivation to students in order to enrich ideas and imagination and encourage them to compose a story flow easily.

In this study, the value related to entrepreneurial aims at disseminating an entrepreneurial character to students. According to Suryana (2007:12), the entrepreneurial value is oriented to a character of self-confidence, creative, innovative and able to take a risk. Individual possessing entrepreneurial value also deals with the task assigned and its result and indeed he or she is possessing leadership characteristic.

\section{METHOD}

The research and development model employed a Borg and Gall (R \& D) model. According to Borg and Gall (1989: 624), educational development research is a process to develop and validate products in the field of education. The selection of research and development R \& D model is expected to discover knowledge or answer to practical problems.

The four main features of research and development according to Borg and Gall (1989) are (1) conducting a preliminary study or research to find the research findings related to the product, (2) developing the product based on the preliminary study, (3) conducting a field trial, and (4) making a revision to improve the weaknesses during the field trials stages.

The first cycle was planning. Planning is the first cycle formulated before the implementation of research and development of learning. Planning in this study, formulate the objectives to be achieved. The research and development objectives are (1) to develop learning strategies for short stories writing with news text conversion strategies encompassing entrepreneurial values, and (2) to test the effectiveness of the product.

The second stage was developing the product. The design of the product developed in this present study is a model of short story writing with news text conversion strategy encompassing entrepreneurship value for students. The team in this study were (1) supervisor, (2) team of experts, (3) practitioners, and (4) students. The supervisors play a role in providing direction and suggestions for improvement of product research development. The expert teams play a role in assessing comments, critiques, and suggestions for product improvement. The practitioner team plays a role in providing information about the MKS course, while students are involved to provide comments, criticisms, and suggestions regarding the usefulness of the product.

The third cycle wass experts and practitioners testing. Expert testing is the process of assessment of the product created. This assessment is done by experts in the field of short story writing lessons. The designated experts are literary learning specialists, entrepreneurial experts, visual design experts, and practitioners. The assessment is done to know the deficiency and excess of the product. The deficiencies found by experts make constructive suggestions for researchers to revise the developed product. 
The four stage was expert testing. The revision of expert test results includes a revised model of learning to write short stories with news text conversion strategies encompassing the value of entrepreneurship for students, consisting of the following.

- The revision comprises a review from the learning expert; (1) learning planning, (2) implementation of learning, (3) learning assessment, and 4) general response

- The review of literature expert consists of (1) the process of reading literary texts, (2) the process of creative and imaginative thinking, (3) the process of writing short stories.

- The review of practitioners consists; (1) learning procedures, (2) feasibility of presentation, (3) general comments.

The fifth stage tests the effectiveness of product design. The effectiveness test was conducted on the students of Indonesian Language and Literature Education Department, involving two classes. It aims at measuring the effect of product usage results. The effectiveness test activity is carried out through quasi-experimental research. What distinguishes the two groups is that the experimental group is treated with short story writing with a text conversion strategy, while the control group is given the conventional treatment.

The sixth stage deals with the revision of effectiveness test results. The revisions of effectiveness test results include content, presentation of stories, and the language used. The story content consists of 1) the suitability of the story with the theme, 2) creativity in developing the story, 3) the completeness of the story, 4) the suitability of the story with the source of the story. The presentation of the story consists of 1) the presentation of elements in the form of characters, plot, point of view, and background story, 2) cohesiveness of story elements, and 3) sequential story sequence. Language, composed; 1) choice of words or diction, 2) compilation of sentences and use of the figurative language.

The seventh stage is final product dissemination and implementation. The process and implementation of the final product are to print out the final product, present the final product, and publish the final product through the scientific forum or scientific journal.

The data collected through assessment and trial consists of two types, namely qualitative and quantitative. The sources of qualitative data were in the form of criticism and suggestions of experts, practitioners, and students. The data were obtained through consultations, discussions, interviews, and through expert review assessments, and user groups. The data was used to review, revise, and refine the product. The quantitative data obtained from the results of the test of effectiveness was in the form of scores of students' ability to write short stories.

\section{RESULTS AND DISCUSSION}

\section{Results}

The learner's strategy to write short stories for the students generally contains two stages, namely the stages of reading news and writing short stories. Both stages are exposed to the parts of the product development. Both stages are described below.

Part 1: Conceptual Stengthening

The concept described in part I is the concept of entrepreneurial, which is one of creative and innovative concept and the concept of news text. The purpose of the presentation of creative and innovative concepts is to enable students to understand the meaning and description of creative and innovative. It aims at instilling the value of the character in composing excellent works and possesses positive expressions in society. Through the story, students are expected to develop themselves to apply creative and innovative values in everyday life.

The presentation of the concept of news aims at understanding the notion of news, elements of news, the process of presenting news and images. This makes it easier for students to critically examine the text presented, and make it easy to convert news texts into short stories.

At the stage of reading the news text, the news text was presented. Students are asked to read critically and analyze it based on the elements of the news. A news element is presented in the questionnaire column. This can be seen in the picture above.

Part 3: Short story writing

Within the part of short story writing, students are asked to combine questions related to the news aspects and questions related to the story. According to the guidance, students are demanded to be able to compose a story framework. Story framework, then, will be developed as a complete story. The instance is presented in the following guidance. 
TABLE 1.

SHORT STORY FRAMEWORK GUIDANCE

\begin{tabular}{|c|c|c|c|}
\hline Guided News Questions & Answers & Guided Story Questions & Answer \\
\hline What event did occur? & $\begin{array}{l}\text { Debris and waste issues of } \\
\text { Gorontalo City Government, both } \\
\text { organic and anorganic waste which } \\
\text { has not been managed optimally }\end{array}$ & $\begin{array}{l}\text { What events are raised in } \\
\text { the story? }\end{array}$ & Personal experience \\
\hline $\begin{array}{l}\text { Who was involved in the } \\
\text { event? }\end{array}$ & $\begin{array}{l}\text { Government of Gorontalo (Mayor) } \\
\text { Journalist }\end{array}$ & $\begin{array}{l}\text { Who are the characters } \\
\text { involved in the story } \\
\text { How is the character of the } \\
\text { character? }\end{array}$ & $\begin{array}{l}\text { I am a loving character and observer. } \\
\text { Haris's father was a loving, caring, } \\
\text { caring, and trying figure without giving } \\
\text { up } \\
\text { Rosa's mother is a quiet and irresponsible } \\
\text { person }\end{array}$ \\
\hline Where did the event occur? & City of Gorontalo & $\begin{array}{l}\text { Where did the story } \\
\text { happen? }\end{array}$ & $\begin{array}{l}\text { At home } \\
\text { Secretariat of Nature Lovers Community }\end{array}$ \\
\hline When did the event occur? & Year 2016 & $\begin{array}{l}\text { When did the story } \\
\text { happen? }\end{array}$ & $\begin{array}{l}\text { Day and night } \\
\text { The atmosphere is sad and happy }\end{array}$ \\
\hline Why did that happen? & $\begin{array}{l}\text { The lack of public knowledge of } \\
\text { organic and non organic waste } \\
\text { management. }\end{array}$ & Why did the story happen? & $\begin{array}{l}\text { Starting from the sadness of the figure } \\
\text { due to losing job } \\
\text { Enterprises of the character in managing } \\
\text { waste }\end{array}$ \\
\hline How did that happen? & $\begin{array}{l}\text { Waste problem in Gorontalo. The } \\
\text { City Government launched the } \\
\text { waste-free program Gorontalo to } \\
\text { minimize the volume of waste. It } \\
\text { was managed professionally. } \\
\text { Before disposal to landfill, the } \\
\text { waste is sorted. Waste that can still } \\
\text { be utilized then be recycled into a } \\
\text { variety of crafts. Organic waste } \\
\text { will be processed into fertilizer or } \\
\text { raw materials for the manufacture } \\
\text { of biogas for household needs. }\end{array}$ & $\begin{array}{l}\text { How does the plot is } \\
\text { developed? }\end{array}$ & $\begin{array}{l}\text { Beginning: } \\
\text { Introduction to the character of a couple } \\
\text { who was previously happy } \\
\text { The figure 'I' represent all-know and } \\
\text { lenient daughter } \\
\text { Having problems in economic terms } \\
\text { The wife left her husband because he } \\
\text { could not stand the family life that has } \\
\text { low income } \\
\text { Husband who tried as much as possible, } \\
\text { especially in waste management } \\
\text { End: } \\
\text { Happy to be rewarded for his } \\
\text { achievements as an environmentalist. }\end{array}$ \\
\hline
\end{tabular}

The next step after determining short story framework, guided questions to direct story's development on imagination aspect was done. Guided questions can be seen in Table 2.

TABLE 2.

STORY DEVELOPMENT GUIDANCE

\begin{tabular}{|c|c|}
\hline Who are you? & - I'm a girl named Andayani \\
\hline What happened to you? & - I am saddened by my family life \\
\hline Who are the characters involved in your life? & - Father and mother \\
\hline How are their characters? & $\begin{array}{l}\text { - Father is a figure of merciful, compassionate, caring, and without giving up } \\
\text { - Mother is a quiet and irresponsible person }\end{array}$ \\
\hline How are you with them? & $\begin{array}{l}\text { - I'm an observer of my Mom and Dad. I love both. Dad loves me too. } \\
\text { - My mother has left me }\end{array}$ \\
\hline What interests them? & - Father patient, creative and hardworking \\
\hline What's your problem with them? & - Father and mother have problems in their household, especially economic problems. \\
\hline When does this problem occur? & $\begin{array}{l}\text { - It started when my mother left home because she was laid off from her job. Father as } \\
\text { her husband was the target of her outrage. }\end{array}$ \\
\hline Where this problem occurs & - In a rented house \\
\hline How the conflict could happen & $\begin{array}{l}\text { - Mother works at an oil company in my neighborhood. Twelve employees are laid off } \\
\text { without severance pay. Including Mom. } \\
\text { - Especially Mom can not control herself. Just a bit of a nuisance to his heart, his anger } \\
\text { flooded. He became rude and often insulted my father. }\end{array}$ \\
\hline How do you deal with this problem? & $\begin{array}{l}\text { - Trying to be patient with everything. Just be able to pray, hopefully, a kind Father } \\
\text { can find a solution to the problem. } \\
\text { - Dad works sincerely } \\
\text { - Meet creative and innovative friends } \\
\text { - Creating something worthwhile. }\end{array}$ \\
\hline What is the wisdom on this issue? & $\begin{array}{l}\text { - Keep trying though experiencing various problems } \\
\text { - Be creative and innovative thinkers to realize something new and valuable. }\end{array}$ \\
\hline $\begin{array}{l}\text { What is the value of entrepreneurship in this } \\
\text { story? }\end{array}$ & $\begin{array}{l}\text { - Have a creative and innovative spirit through waste recycling. (Creative and } \\
\text { Innovative) } \\
\text { - Dad walked around four villages to collect garbage and used goods. With this } \\
\text { livelihood, the way Father made me happy. Provide and meet the needs of my school. } \\
\text { (Hard Work) } \\
\text { - I so know, when my father and community friends separate organic and inorganic } \\
\text { waste. Dad chose anorgnik trash like glass bottles, plastic bottles, k a leng, and paper. } \\
\text { The goods are reprocessed into useful items. I never saw my father working late nights } \\
\text { cans to recycle back into something unique and nice as accessories or toys. } \\
\text { (Understanding the Work Procedure: Plan, Create, Produce creativity) }\end{array}$ \\
\hline
\end{tabular}


At the discussion stage, the activity conducted was reading the work that has been given to the partner to be assessed and given advice. The discussion process is described below.

The short story composed by students were exchanged with the peers to be read, corrected, and given advice. Guided questions to revise the short story is presented the following details.

1. Figure and Characterization

- Does it depict character's character?

- Does the character portray directly?

- Does it describe the circumstances surrounding the character?

- Does it reflect the reaction of other characters to the main character?

- Does it characterize character through dialogue between characters?

- Does it depict the actions of the characters?

2. Storyline

- What problems arise?

- What are other problems being developed in the stages of the dispute?

- What is the climax point? Is it resolved?

- How to resolve the issue?

- Is unity integrated story? Are there unnecessary scenes?

3. Background Story

- Does the background support the quality of the story?

- Does the background support each character's role?

- Does the background support the storyline?

- Does the background support themes and messages?

- In what period of time does the work take place?

4. Themes and the Message

- Does the character of a character support a creative and innovative theme?

- Does the storyline represent the theme and the message?

- Does this story give a good impression?

- Does this story provide insight into various aspects of life?

\section{DisCUSSION}

According to the result, in general, the model is considered feasible to be used to support writing course, particularly in writing short story. The general comments obtained from expert and practitioner testing are: (1) there is a need of learning product development, for students, to motivate them in achieving the competence of the course, (2) the product assists students to practice writing, (3) the presentation of product assists students to understand, analyze, and create short story, (4) in addition, it assists the students easily to discover the creation of ideas, the determination of the story framework, and the process of writing stories.

Product effectiveness test was conducted to obtain the result of product usage. To know the effectiveness of the product then trial to the student in the learning process was conducted. The experiment class of this study was a $3 \mathrm{~B}$ Class which consists of 25 students. Meanwhile, the control class of this study was a 3C Class which consists of 26 students. The experiment activity to both experiment and control group was done in three phases, (1) pre-test, (2) treatment, and (3) post-test. The control group was also being employed as an experiment activity, however, they did not treat using learning model developed. Instead, conventional learning model for short story writing course was employed.

Based on the result of the learning process in 3B Class (experimental group) and 3C Class (control group), the data of t-test result showed that the mean difference between the experiment class and control class score was 11.38923 and the experiment class score is higher than the control group. The standard error mean is 0.85540 and at the $95 \%$ confidence level the lowest average difference is 8.76464 and the highest average difference is 14.01382. In addition, $t$-test results obtained by the count value of 8,720 with $\mathrm{df}=49$ and significant at the level of 0.000 . This can be seen in the following graph. 

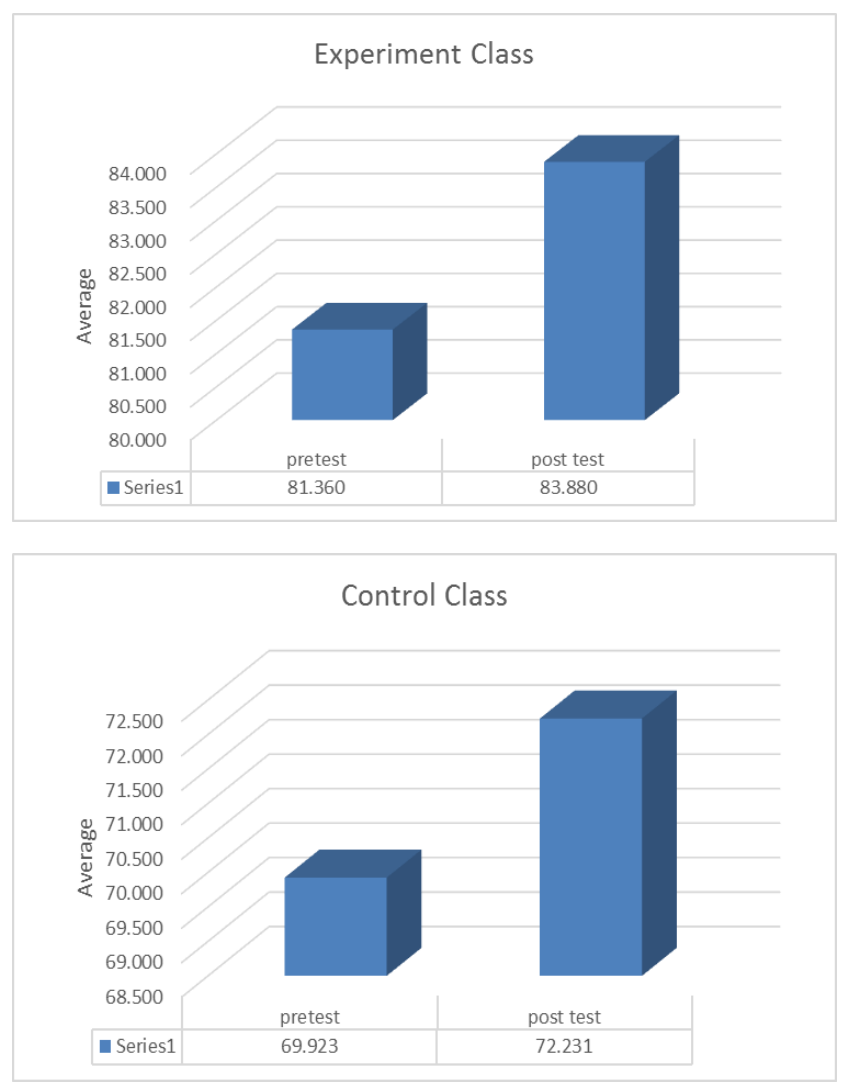

The results of data processing can be described below. (1) If sig $\leq 0.05$ then the mean of both groups differ significantly. From the data known sig $(2$ tailed $)=0.000$ then $0.000 \leq 0.05$, therefore it can be concluded that the average score of the experimental class and the control class score differ significantly. (2) Based on homogeneity test, if sig $\geq 0.05$ then both groups are considered homogeneous. The data shows that $\operatorname{sig}=0.308$. So it can be concluded that both groups belong to a homogeneous group. (3) Thus, the 3B experimental class students had a higher average score than the $3 \mathrm{C}$ control class students. Thus it can be argued that the use of Learning Model of Short Stories Writing with Text Conversion Strategies encompassing entrepreneurial values significantly influence the ability to write short story text. Thus, the use of such products can improve the effectiveness of short story text writing skills.

\section{CONCLUSION}

Based on the above description, it can be concluded that writing a story can be done through the conversion of news texts. The news media is the preferred way of developing a story writing lesson. Creative writing is the development of skills to explore competence in understanding discourse, both as a reader and as a writer. Given the importance of the ability to write a story, particularly in the course of writing text, it is suggested in further research to develop a media of learning in writing text, especially writing works of literature.

\section{REFERENCES}

[1] Anshori, et. al. (2005). Bahasa Jurnalistik. Bandung: Pusat Studi Literasi FPBS UPI

[2] Eggen, Paul and Don Kauchak. (2012). Strategi dan Model Pembelajaran. Jakarta: PT Indeks

[3] Fisher, Douglas, and Gay Ivey. (2002). Literacy And Language As Learning In Content Area Classes: A Departure From "Every Teacher A Teacher Of Reading. Action in Teacher Education Volume 27 Number 2 p3-11.

[4] Gall, Joyce P. Gall and Walter R. Borg. (2003). Educational Research an Introduction. New York: AB

[5] Hasanah, Muakibatul dan Wahyudi Siswanto. (2013). Mengenal Proses Kreatif Sastrawan Indonesia. Malang: Cakrawala Indonesia

[6] Iskandarwassid dan Dadang Sunendar. (2008). Strategi Pembelajaran Bahasa. Bandung: Rosda

[7] Jauhari, Heri. (2013). Terampil Mengarang. Bandung: Nuansa Cendekia

[8] Laksana, A.S. (2013). Creative Writing. Jakarta: Gagas Media

[9] Siswanto, Wahyudi. (2014). Cara Menulis Cerita. Malang: Aditya Media Oublishing.

[10] Suryana. (2004). Memahami Karakteristik Kewirausahaan. Direktorat Pendidikan Menengah Kejuruan. Departemen Pendidikan Nasional. 
Sitti Rachmie Masie was born in Gorontalo $8^{\text {th }}$ in April 1980. She earned her Bachelor Degree in Education in Institute of Teacher Training Gorontalo in 2003 and gained her master degree in Universitas Negeri Malang at 2009. Currently, she is struggling to obtain her Doctoral degree in Education from University Negeri Malang. She is currently a lecturer of Indonesian Language Teaching in Universitas Negeri Gorontalo. She is an active researcher of language and literature teaching.

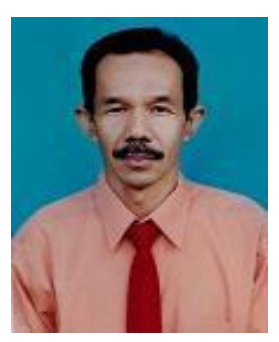

Wahyudi Siswanto was born on Kepanjen February, $20^{\text {th }}$ 1965. He earned his Bachelor Degree in Indonesian Language Teaching from IKIP Malang (currently Universitas Negeri Malang) in 1987 and obtained the master degree and doctoral degree at the same institution in 1991 and 2003. He is currently active as Indonesian Language Teaching Lecturer in Universitas Negeri Malang. In 2010, he was officially acknowledged as Indonesian Language Teaching Professor of Universitas Negeri Malang.

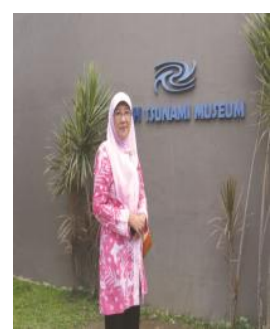

Yuni Pratiwi was born in East Java June $3^{\text {rd, }}$ 1961. He earned his Bachelor Degree in Indonesian Language Teaching from IKIP Malang (currently Universitas Negeri Malang) in 1984 and obtained the master degree and doctoral degree at the same institution in 1995 and 2006. She is currently taking a role as Study Program Coordinator of Indonesian Language Teaching in Graduate School Universitas Negeri Malang.

Heri Suwignyo was born in East Java May, 21st 1965. He earned his Bachelor Degree in Indonesian Language Teaching from IKIP Malang (currently Universitas Negeri Malang) in 1986 and obtained the master degree and doctoral degree at the same institution in 1997 and 2009. He is currently active as Indonesian Language Teaching Lecturer in Universitas Negeri Malang and taking a role as Head Department of Indonesian Language and Literature Teaching Faculty of Letters Universitas Negeri Malang. 